\title{
Back to Methuselah: II
}

\section{LADY GREGORY}

From Lady Gregory's Journals 1916-1930, ed. Lennox Robinson (London: Putnam, 1946) pp. 202-4. The following accounts of Shaw's reading of various parts of Back to Methuselah are recorded in Lady Gregory's journal entries for 3 March 1919. She was staying with the Shaws at Ayot St Lawrence.

Last night . . . he gave an account of a wonderful and fantastic play he is writing beginning in the Garden of Eden before Adam and Eve, with Lilith who finds a lonely immortality impossible to face and so gives herself up to be divided into Man and Woman. ${ }^{1}$ He read a scene in it (on the pier at Burren) about a thousand years in the future with the Irish coming back to kiss the earth of Ireland and not liking it when they see it. ${ }^{2}$

GBS read me his play beginning in the Garden of Eden. The first act a fine thing, 'a Resurrection Play' I called it. The second, two hundred years later, an argument between Cain, Adam and Eve, the soldier against the man of peace. I told him I thought it rather monotonous, an Ossianic dialogue, ${ }^{3}$ and he said that he thought of introducing Cain's wife, 'the Modern Woman', or perhaps only speaking of her in the argument. ${ }^{4}$ I said even that would be an improvement as Cain is unnecessarily disagreeable and one could forgive if he is put, by aspersions on his wife, in a passion, for one can forgive where there is passion. It is like drunkenness - 'Ah, you can't blame him, he was drunk', when a man has cut your head open. He laughed and agreed or seemed to.

\section{NOTES}

1. In Act I of the first play of the cycle, 'In the Beginning', the Serpent tells Eve this story of Lilith dividing herself into Adam and Eve.

2. The reference is to part Iv of the cycle, 'Tragedy of an Elderly Gentleman'.

3. I.e. in the manner of the bardic Ossianic poems of James Macpherson (1736-96).

4. Cain's wife, Lua, is the subject of several passages of dialogue in Act II of 'In the Beginning'. She is described as a manipulative femme fatale. 